\title{
Implementasi Model Transportasi pada Distribusi LPG (Liquid Petroleum Gas) 3 Kg di Sulawesi Utara
}

\author{
Leony Sisilia Arifin ${ }^{1}$, Marline S Paendong ${ }^{2}$, Yohanes A R Langi ${ }^{3 *}$ \\ ${ }^{123}$ Program Studi Matematika, Fakultas Matematika dan Ilmu Pengetahuan Alam, \\ Universitas Sam Ratulangi Manado \\ *corresponding author email : yarlangi@gmail.com
}

\begin{abstract}
Abstrak
Penelitian ini bertujuan untuk mengetahui penerapan model transportasi distribusi tabung gas LPG $3 \mathrm{~kg}$ di Sulawesi Utara. Penelitian ini dilakukan di dua SPPBE (Stasiun Pengisian dan Pengangkutan Bulk Elpiji) milik PT PERTAMINA (PERSERO) yang merupakan perusahaan minyak gas dan bumi yaitu SPPBE Tambang Yoko Delta dan SPPBE Sinar Pratama Cemerlang. Adapun kegunaan dari penelitian ini untuk meningkatkan dan memperbaiki sistem distribusi perusahaan. Metode analisis yang digunakan adalah menggunakan model transportasi. Dari hasil penelitian dan perhitungan diperoleh hasil bahwa perusahaan mengeluarkan biaya transportasi dalam mendistribusikan LPG 3KG dalam setahunnya sebesar Rp. 2.679.767.000 dengan jumlah produk sebanyak 16.117.840 tabung LPG $3 \mathrm{Kg}$.
\end{abstract}

Kata kunci: metode transportasi, tabung gas LPG 3 kg, Vogel's Approximation Method, POM-QM for windows

\section{The Implementation of Transportation Model on Distribution of LPG (Liquid Petroleum Gasses) 3 Kg in North Sulawesi}

\begin{abstract}
This study aims to understand the application of transport model on LPG $3 \mathrm{~kg}$ distribution in North Sulawesi. This research was conducted in two SPPBE (Stasiun Pengisian dan Pengangkutan Bulk Elpiji) owned by PT PERTAMINA (PERSERO) which is an oil and natural gas corporation is SPPBE Sinar Pratama Cemerlang and SPPBE Tambang Yoko Delta. The purpose of this study was enhance and improve the corporation's distribution. The analytical method used in this research is transportation model. The result of the analysis and calculation showed that the company issued in distributing LPG transportation costs by Rp. 2.679.767.000 in a year with the number of product by 16.117.840 LPG $3 \mathrm{Kg}$.
\end{abstract}

Keywords: transportation method, LPG (Liquid Petroleum Gasses) $3 \mathrm{~kg}$, Vogel's Approximation Method, $P O M-Q M$ for windows

\section{Pendahuluan}

Sejak tahun 2004, setiap tahunnya pemerintah menganggarkan dana sekitar Rp. 70 Triliun untuk mensubsidi BBM, yaitu minyak tanah, premium, dan solar. Dari ketiga jenis bahan bakar ini, minyak tanah adalah jenis bahan bakar yang mendapat subsidi terbesar karena lebih dari 50\% anggaran subsidi BBM digunakan untuk subsidi minyak tanah. Dari tahun ke tahun anggaran pemerintah untuk subsidi BBM semakin tinggi, sedangkan harga minyak dunia yang cenderung meningkat. Oleh karena itu, pemerintah berusaha keras untuk memenuhi kebutuhan warga negaranya yang bersifat primer ini. Banyak sumber yang sedang diteliti sebagai bahan bakar alternatif, salah satunya adalah bahan bakar gas berupa LPG (Liquid Petroleum Gas), sehingga pada tahun 2007 Pemerintah membuat kebijakan yaitu pengalihan subsidi minyak tanah ke LPG.

Proses distribusi LPG berawal dari pengadaan LPG yang diproduksi dari kilang dalam negeri maupun import, yang selanjutnya didistribusikan ke depot-depot LPG. Dari depot inilah selanjutnya disalurkan ke SPPBE dan mulai dilakukan pengisian ke dalam tabung LPG 3kg dan selanjutnya akan disalurkan ke agen-agen LPG. Kemudian agen LPG ini mendistribusikannya ke sub-sub agen LPG. Oleh karena itu, sistem pendistribusian tersebut perlu diatur secara sistematis dan perlu dilakukan 
optimasi distribusi dari titik supply sampai ke tujuannya untuk mengetahui keefektifan sistem distribusi tersebut [1].

SPPBE (Stasiun Pengisian dan Pengangkutan Bulk Elpiji) adalah salah satu stasiun yang bertugas dalam melakukan penyaluran LPG ke agen-agen, dan tentunya membutuhkan biaya transportasi yang tidak sedikit jumlahnya. Untuk itu diperlukan perencanaan yang matang agar biaya transportasi yang dikeluarkan seefisien mungkin dan tidak menjadi persoalan yang dapat menguras biaya besar.

Model transportasi dengan perhitungan manual memerlukan waktu yang lama dan tidak efisien, oleh karena itu model transportasi tersebut akan di coba diimplementasikan dalam bentuk perangkat lunak untuk mempermudah proses perhitungan untuk mendapatkan biaya transportasi yang optimal.

\section{Sistem Distribusi LPG}

LPG (Liquified Petroleum Gasses) merupakan salah satu produk bahan bakar gas yang pada umumnya berupa gas propana $\left(\mathrm{C}_{3} \mathrm{H}_{8}\right)$ dan butana $\left(\mathrm{C}_{4} \mathrm{H}_{10}\right)$ atau merupakan campuran antara keduanya yang dalam suhu atau temperature kamar akan berbentuk dalam fasa gas tetapi dalam tekanan tinggi atau pada suhu sangat rendah akan berbentuk cair yang tidak berasa, tidak berwarna atau tidak berbau.

Jalur distribusi adalah salah satu jalur dimana produk dan kepemilikan secara hukum mengalir dari produsen ke konsumen. Berikut ini merupakan pola jalur distribusi LPG secara keseluruhan

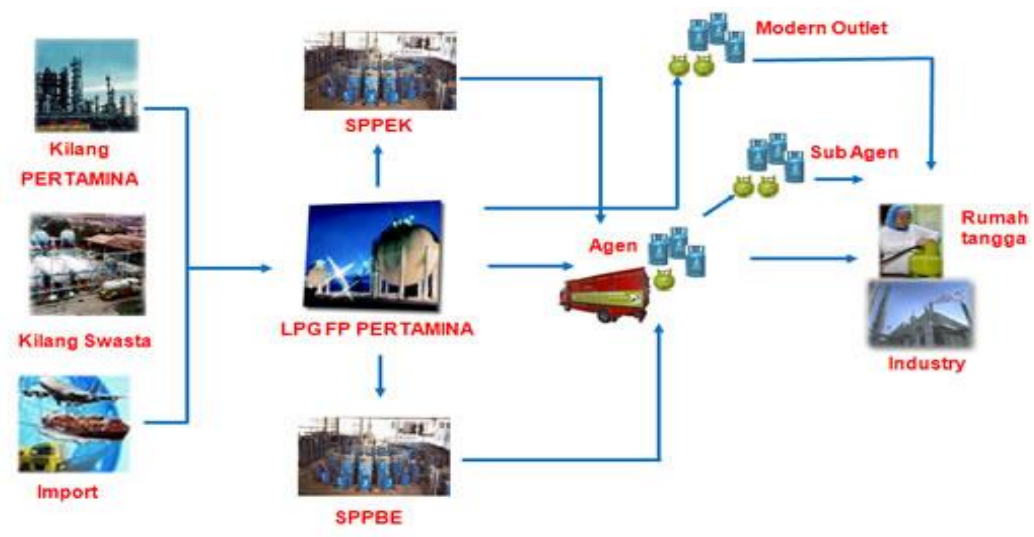

Gambar 1. Pola jalur distribusi LPG

SPPBE (Stasiun Pengisian dan Pengangkutan Bulk Elpiji) merupakan filling plant yang bertugas melakukan pengangkutan, pengisian, dan penyaluran LPG dalam bentuk tabung maupun curah untuk para agen, dimana filling fee dan transportation fee yang ditanggung oleh Pertamina untuk setiap LPG yang diisikan pada tabung, sedangkan SPPEK (Stasiun Pengisian dan Pengiman LPG Khusus) merupakan mini filling plant yang terletak di remote area. dimana filling fee ditanggung oleh Pertamina sedangkan transportation fee ditanggung oleh konsumen (dimasukkan dalam struktur harga jual)[2].

\section{Metode Transportasi}

Model transportasi merupakan suatu model khusus yang dikembangkan untuk memecahkan masalah-masalah yang berhubungan dengan transportasi (pengangkutan) dan disribusi produk atau sumber daya dari berbagai sumber (pusat pengadaan, atau titik supply) ke berbagai tujuan (titik permintaan atau pusat pemakaian) yang lebih efisien dalam hal perhitungan.[3]

Suatu model transportasi dikatakan seimbang apabila total supply (sumber) sama dengan total demand (tujuan). Dengan kata lain:

$$
\sum_{i=1}^{m} a_{i}=\sum_{j=1}^{n} b_{j}
$$


Dalam persoalan transportasi yang sebenarnya, batasan ini tidak selalu terpenuhi atau dengan kata lain jumlah supply yang tersedia mungkin lebih besar atau lebih kecil daripada jumlah demand. Jika hal ini yang terjadi, maka persoalan transportasi dapat dibuat seimbang dengan memasukkan kolom dummy atau baris dummy.

Ongkos transportasi per unit $\left(\mathrm{C}_{\mathrm{ij}}\right)$ dari sumber dummy ke seluruh tujuan adalah nol. Hal ini dapat dipahami karena pada kenyataan dari sumber dummy tidak terjadi pengiriman [4].

\subsection{Asumsi Metode Transportasi}

Asumsi dasar dari model transportasi ini adalah biaya transportasi di sebuah rute tertentu adalah proposional secara langsung dengan jumlah unit yang dikirimkan. Ciri-ciri khususnya adalah :

1. Terdapat sejumlah sumber dan sejumlah tujuan tertentu.

2. Kuantitas komoditas atau barang yang didistribusikan dari setiap sumber dan yang diminta oleh setiap tujuan besarnya tertentu.

3. Komoditas yang dikirim atau diangkut dari suatu sumber ke suatu tujuan besarnya sesuai dengan permintaan dan kapasitas sumber.

4. Ongkos pengangkutan komoditas dari suatu sumber ke suatu tujuan besarnya tertentu.

\subsection{Diagram Metode Transportasi}

Sebuah model transportasi dari sebuah jaringan dengan $m$ sumber dan $n$ tujuan. Sebuah sumber atau tujuan diwakili dengan sebuah node, busur yang menghubungkan sebuah sumber dan sebuah tujuan mewakili rute pengiriman barang tersebut. Jumlah penawaran di sumber $i$ adalah $a_{\mathrm{i}}$ dan permintaan di tujuan $j$ adalah $b_{j}$. Biaya unit transportasi antara sumber i dan tujuan $\mathrm{j}$ adalah $C_{i j}$. Anggaplah $X_{i j}$ mewakili jumlah barang yang dikirimkan dari sumber $i$ ke tujuan $j$ [5].

Secara diagramatik, model transportasi dapat digambarkan sebagai berikut:

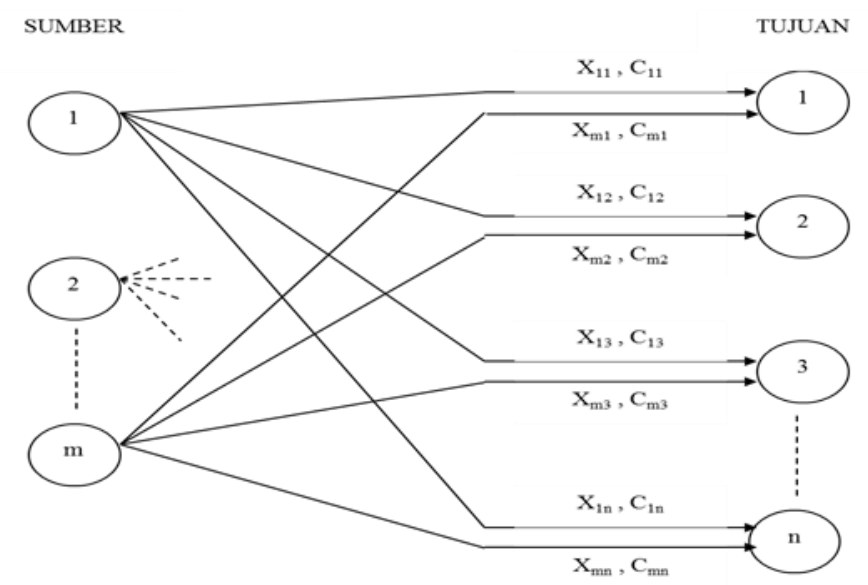

Gambar 2. Diagram model transportasi

Dari gambar diagram model transportasi tersebut berlaku :

- Masing-masing sumber mempunyai kapasitas $a_{i}$ dengan $i=1,2,3, \ldots, m$

- Masing-masing tujuan membutuhkan komoditas $b_{j}$ dengan $j=1,2,3, \ldots, n$

- Jumlah unit yang dikirim oleh sumber ke-i kepada tujuan ke-j adalah sebanyak $X_{\mathrm{ij}}$ dengan $\mathrm{i}=1,2,3, \ldots, \mathrm{m}$ dan $\mathrm{j}=1,2,3, \ldots, \mathrm{n}$

- Biaya pengiriman per unit dari sumber ke-i kepada tujuan ke-j adalah sebanyak $C_{i j}$ dengan $\mathrm{i}=1,2,3, \ldots, \mathrm{m}$ dan $\mathrm{j}=1,2,3, \ldots, \mathrm{n}$ 


\subsection{Formulasi Model Transportasi}

Formulasi dari model transportasi ini adalah

Fungsi tujuan :

$$
\min Z=\sum_{i=1}^{m} \sum_{j=1}^{n} X_{i j} C_{i j}
$$

Fungsi Pembatas :

$$
\begin{aligned}
& \sum_{j=1}^{n} X_{i j}=a, \quad i=1,2,3, \ldots, m \\
& \sum_{i=1}^{m} X_{i j}=b, j=1,2,3, \ldots, n \\
& X_{\mathrm{ij}} \geq 0 \text { untuk semua I dan } \mathrm{j}
\end{aligned}
$$

Jika total supply $\left(\sum a_{i}\right)=$ total demand $\left(\sum b_{j}\right)$, maka formulasi yang dihasilkan disebut sebagai model transportasi seimbang. Perbedaannya dengan bentuk formulasi standar hanya pada penggunaan persamaan pada kendala, yaitu

$$
\begin{array}{ll}
\sum X_{i j}=a_{i}, & i=1,2, \ldots, m \\
\sum X_{i j}=b_{j}, & j=1,2, \ldots, n
\end{array}
$$

Tabel permasalahan transportasinya adalah sebagai berikut

Tabel 1. Model Umum Transportasi

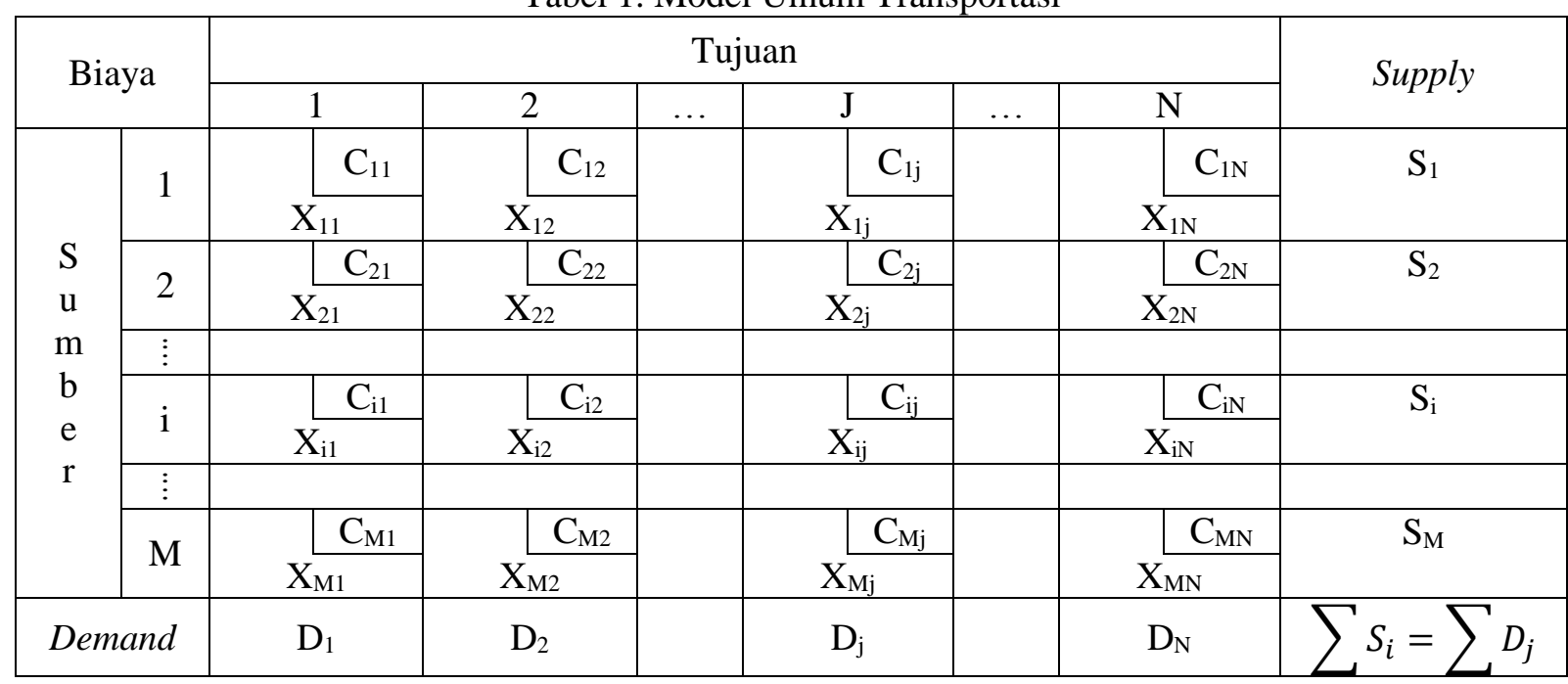

Sebuah matriks memiliki $\mathrm{n}$ baris dan $\mathrm{m}$ kolom. Pada matriks transportasi sumber-sumber terletak pada baris, sedangkan tujuan-tujuan terletak pada kolom. Notasi i digunakan untuk menandai baris ke-i, sedang notasi $\mathrm{j}$ digunakan untuk menandai kolom ke-j.

Dengan demikian :

$\mathrm{X}_{\mathrm{ij}} \quad$ :Banyaknya unit produk atau barang yang akan dikirim dari sumber ke $-\mathrm{i}$ menuju tujuan ke-j

$\mathrm{C}_{\mathrm{ij}} \quad$ : Harga transport barang per unit dari sumber i ke tujuan $\mathrm{j}$

$\mathrm{S}_{\mathrm{i}} \quad$ : Kapasitas dari sumber ke-i

$\mathrm{D}_{\mathrm{j}} \quad$ : Banyaknya permintaan barang dari tujuan ke-j [6]. 


\subsection{Langkah - Langkah Metode Transportasi}

Model transportasi saat dikenali pertama kali diselesaikan secara manual dengan menggunakan algoritma yang dikenal sebagai algoritma transportasi

1. Pertama, diagnosis masalah dimulai dengan pengenalan sumber, tujuan, parameter dan variabel.

2. Kedua, seluruh informasi tersebut kemudian dituangkan ke dalam matriks transportasi.

3. Ketiga, setelah matriks transportasi terbentuk kemudian dimulai menyusun tabel awal. Alogaritma transportasi mengenal tiga macam metode untuk menyusun tabel awal, yaitu:

- Metode Biaya Terkecil (Least Cost Method)

- Metode Sudut Barat Laut (North West Corner Method)

- VAM (Vogel's Approximation Method)

4. Keempat, setelah penyusunan tabel awal selesai maka sebagai langkah selanjutnya adalah pengujian optimalitas tabel untuk mengetahui apakah biaya distribusi total telah minimum. Ada dua macam pengujian optimalitas alogaritma transportasi:

- Metode Batu Loncatan (Stepping Stone Method)

- MODI (Modified Distribution Method)

5. Kelima, atau langkah yang terakhir adalah revisi tabel bila dalam langkah keempat terbukti bahwa tabel belum optimal atau biaya distribusi total masih mungkin diturunkan lagi. Dengan demikian, jelas sekali bahwa langkah kelima ini tidak akan dilakukan apabila pada langkah keempat telah membuktikan bahwa tabel telah optimal [7].

\section{Metode Penelitian}

\subsection{Tahapan Analisis Data}

Metode pengumpulan data yang dilakukan adalah sebagai berikut

1. Melakukan observasi atau pengamatan secara langsung pada perusahaan Pertamina Manado untuk mendapatkan data-data yang diperlukan sehubungan dengan penelitian ini.

2. Melakukan tanya jawab secara langsung pada salah satu pihak di tiap SPPBE tentang objek yang sedang diteliti untuk mendapatkan data atau informasi yang diperlukan.

3. Mengumpulkan dokumen atau arsip-arsip milik SPPBE yang berhubungan dengan masalah distribusi.

4. Mengimplementasikan data dengan vogel's approximation method pada biaya distribusi dengan menggunakan aplikasi POM QM for windows.

\subsection{Penyelesaian VAM (Vogel's Approximation Method)}

Metode Pendekatan Vogel merupakan metode yang lebih mudah dan lebih cepat untuk mengatur alokasi dari beberapa sumber ke beberapa daerah yang membutuhkan. Langkah-langkah untuk mengerjakannya adalah sebagai berikut

a. Susunlah kebutuhan, kapasitas masing-masing sumber dan biaya pengangkutan ke dalam matriks.

b. Carilah perbedaan dari dua biaya terkecil (dari nilai absolute), yaitu biaya terkecil kedua untuk setiap baris dan kolom.

c. Pilih satu nilai perbedaan-perbedaan tersebut di antara semua nilai perbedaan pada kolom dan baris.

d. Isilah pada satu segi empat yang termasuk dalam kolom atau baris terpilih, yaitu pada segi empat yang biayanya terendah di antara segi empat yang lain pada kolom atau baris itu. Isinya sebanyak mungkin yang bisa dilakukan.

e. Hilangkan baris atau kolom tersebut karena baris atau kolom tersebut sudah diisi sepenuhnya sehingga tidak mungkin diisi lagi.

f. Tentukan kembali perbedan (selisih) biaya pada langkah b untuk kolom dan baris yang belum terisi. Ulangi langkah c sampai dengan langkah e, sampai semua kolom dan baris teralokasi.

g. Setelah terisi semua, hitung biaya transportasi secara keseluruhan.[8] 


\section{Hasil dan Pembahasan}

\subsection{Jenis Transportasi}

Dalam mendistribusikan LPG $3 \mathrm{~kg}$ dari gudang atau SPPBE ke setiap daerah tujuan atau agen, tiap SPPBE menggunakan mobil dengan jenis truck sesuai standarisasi PT PERTAMINA (PERSERO).

\subsection{Gambaran Umum Daerah Asal Dan Daerah Tujuan Distribusi}

\subsubsection{Daerah Asal}

Dalam mendistribusikan LPG 3kg, perusahaan PT. Pertamina memiliki 2 SPPBE sebagai daerah asal, diantaranya

a SPPBE Sinar Pratama Cemerlang

Alamat: Jalan Lengkong Wuaya, Liwas, Paal Dua, Kota Manado, Sulawesi Utara

b SPPBE Tambang Yoko Delta

Alamat: Jl. Watungkas, Matungkas, Dimembe, Kabupaten Minahasa Utara, Sulawesi Utara

\subsubsection{Daerah Tujuan}

Seperti halnya daerah asal, tiap SPPBE memiliki daerah tujuan distribusi ke beberapa agen yang tersebar di Sulawesi Utara, antara lain

1. Manado: kecamatan tuminting

2. Tomohon: kelurahan kakaskasen

3. Minahasa: kecamatan langowan

4. Minahasa selatan: kecamatan modoinding

5. Minahasa utara: kecamatan dimembe

6. Bolaang mongondow: kecamatan dumoga timur

7. Minahasa tenggara: kecamatan tombatu

8. Kotamobagu: kelurahan kotabangun

\subsection{Supply and Demand LPG 3kg}

Adapun kapasitas supply daerah asal dan jumlah demand daerah tujuan, antara lain:

1. Kapasitas supply dari daerah asal yaitu

$>$ SPPBE Sinar Pratama Cemerlang

$>$ SPPBE Tambang Yoko Delta

2. Jumlah demand daerah tujuan yaitu

$>$ Manado

$>$ Tomohon

$>$ Minahasa

$>$ Minahasa selatan

$>$ Minahasa utara

$>$ Bolaang mongondow

$>$ Minahasa tenggara

$>$ Kotamobagu

Adapun tiap mobil pengangkutan berisi 560 tabung LPG 3kg.
$=9.138 .600$ tabung/tahun

$=6.979 .240$ tabung/tahun

$=7.276 .600$ tabung/tahun

$=1.213 .520$ tabung/tahun

$=2.570 .920$ tabung/tahun

$=1.240 .400$ tabung/tahun

$=1.083 .040$ tabung/tahun

$=416.640$ tabung $/$ tahun

$=852.320$ tabung/tahun

$=1.464 .400$ tabung/tahun

\subsection{Data Transportasi}

\subsubsection{Jarak Dari Daerah Asal (SPPBE) Ke Daerah Tujuan (Agen-Agen) Dalam Kilometer} (Km)

Tabel 2. Jarak Transportasi (dalam KM) Dari Daerah Asal Ke Daerah Tujuan

\begin{tabular}{|c|c|c|c|c|c|c|c|c|}
\hline & MANADO & TOMOHON & MINAHASA & MINSEL & MINUT & BOLMONG & MITRA & KOTAMOBAGU \\
\hline TYD & 20 & 39 & 47 & 104 & 9 & 219 & 93 & 196 \\
\hline SPC & 6 & 32 & 48 & 89 & 17 & 205 & 83 & 186 \\
\hline
\end{tabular}




\subsubsection{Biaya Transpotasi}

Biaya transportasi diperoleh dari penjumlahan biaya bensin per tabung dan upah pekerja untuk per tabungnya, dimana

$$
\begin{aligned}
\text { biaya bensin per tabung } & =\frac{\text { biaya bensin setahun }}{\text { jumlah tabung setahun }} \\
& =\frac{(\text { harga solar } * \text { jarak tempuh })}{\text { jumlah tabung setahun }}
\end{aligned}
$$

Harga solar tahun 2015 adalah 6600 rupiah dengan asumsi 1 liter solar dapat digunakan mobil truck toyota dyna untuk jarak tempuh $10 \mathrm{~km}$ dalam mendistribusikan tabung LPG $3 \mathrm{~kg}$. Jumlah pendistribusian tabung LPG $3 \mathrm{~kg}$ dalam setahun disajikan pada tabel 3.

Tabel 3. Jumlah Distrbibusi LPG 3kg dalam Setahun

\begin{tabular}{|c|c|c|c|c|c|c|c|c|}
\hline & MANADO & TOMOHON & MINAHASA & MINSEL & MINUT & BOLMONG & MITRA & KOTAMOBAGU \\
\hline TYD & 4196040 & 675360 & 385280 & 376880 & 193200 & 113120 & 370160 & 669200 \\
\hline SPC & 3080560 & 538160 & 2185640 & 863520 & 889840 & 303520 & 482160 & 795200 \\
\hline
\end{tabular}

Biaya bensin per tabungnya dalam satuan rupiah disajikan pada tabel

Tabel 4. Biaya Bensin (dalam rupiah) per Tabung

\begin{tabular}{|l|c|c|c|c|c|c|c|c|}
\hline & MANADO & TOMOHON & MINAHASA & MINSEL & MINUT & BOLMONG & MITRA & KOTAMOBAGU \\
\hline TYD & 47 & 92 & 111 & 245 & 21 & 516 & 219 & 462 \\
\hline SPC & 14 & 75 & 113 & 210 & 40 & 483 & 196 & 438 \\
\hline
\end{tabular}

Kemudian untuk memperoleh upah pekerja per tabungnya yaitu

$$
\text { upah per tabung }=\frac{\text { upah kerja harian }}{\text { jumlah tabung harian }}
$$

Upah Minimum Pekerja (UMP) Sulawesi Utara tahun 2015 yaitu 2.150.000 rupiah, sedangkan untuk sekali pendistribusian dilakukan oleh 2 pekerja. Untuk jumlah hari kerja setahunnya disajikan pada tabel 5 .

Tabel 5. Jumlah Hari Kerja dalam Setahun

\begin{tabular}{|c|c|c|c|c|c|c|c|c|}
\hline & MANADO & TOMOHON & MINAHASA & MINSEL & MINUT & BOLMONG & MITRA & KOTAMOBAGU \\
\hline TYD & 289 & 288 & 280 & 282 & 258 & 88 & 248 & 266 \\
\hline SPC & 288 & 292 & 285 & 282 & 264 & 152 & 251 & 267 \\
\hline
\end{tabular}

Upah pekerja untuk per tabungnya dalam satuan rupiah disajikan pada tabel 6.

Tabel 6. Upah Pekerja (dalam Rupiah) untuk per Tabungnya

\begin{tabular}{|c|c|c|c|c|c|c|c|c|}
\hline & MANADO & TOMOHON & MINAHASA & MINSEL & MINUT & BOLMONG & MITRA & KOTAMOBAGU \\
\hline TYD & 12 & 76 & 134 & 137 & 267 & 456 & 139 & 77 \\
\hline SPC & 16 & 956 & 24 & 60 & 58 & 170 & 107 & 65 \\
\hline
\end{tabular}

Untuk biaya transportasi yang diperoleh dari penjumlahan biaya bensin per tabung dengan upah pekerja untuk per tabungnya, maka hasil selengkapnya dapat dilihat melalui tabel 7, disajikan dalam bentuk rupiah/tabungnya.

Tabel 7. Biaya Transportasi (dalam Rupiah)

\begin{tabular}{|c|c|c|c|c|c|c|c|c|}
\hline & MANADO & TOMOHON & MINAHASA & MINSEL & MINUT & BOLMONG & MITRA & KOTAMOBAGU \\
\hline TYD & 59 & 168 & 245 & 382 & 289 & 973 & 359 & 539 \\
\hline SPC & 50 & 171 & 137 & 270 & 98 & 653 & 303 & 503 \\
\hline
\end{tabular}




\subsubsection{Representasi Dalam Bentuk Linear Programming}

Formulasi dari model transportasi ini adalah

Fungsi Tujuan: $\operatorname{Min} Z=59 X_{11}+168 X_{12}+245 X_{13}+382 X_{14}+289 X_{15}+973 X_{16}+359 X_{17}+$ $539 X_{18}+50 X_{21}+171 X_{22}+137 X_{23}+270 X_{24}+98 X_{25}+$

Fungsi Kendala :

$$
653 X_{26}+303 X_{27}+503 X_{28}
$$

a Kapasitas SPPBE (gudang):

$$
\begin{aligned}
& X_{11}+X_{12}+X_{13}+X_{14}+X_{15}+X_{16}+X_{17}+X_{18} \leq 9.138 .600 \\
& X_{21}+X_{22}+X_{23}+X_{24}+X_{25}+X_{26}+X_{27}+X_{28} \leq 6.979 .240
\end{aligned}
$$

b Permintaan Agen (tujuan):

$$
\begin{gathered}
X_{11}+X_{21}=7.276 .600 \\
X_{21}+X_{22}=1.213 .520 \\
X_{13}+X_{23}=2.570 .920 \\
X_{14}+X_{24}=1.240 .400 \\
X_{15}+X_{25}=1.083 .040 \\
X_{16}+X_{26}=416.640 \\
X_{17}+X_{27}=852.320 \\
X_{18}+X_{28}=1.464 .400
\end{gathered}
$$

c Non-negativity: $X_{\mathrm{ij}} \geq 0$, untuk $\mathrm{i}=1,2$ dan $\mathrm{j}=1,2,3,4,5,6,7,8$ dengan $\mathrm{X}_{\mathrm{ij}}$ adalah jumlah tabung gas LPG $3 \mathrm{~kg}$ yang dikirimkan dari sumber $\mathrm{i}$ (SPPBE) ke tujuan $\mathrm{j}$ (agen-agen).

\subsection{Penyelesaian Model Transportasi Distribusi LPG 3kg Menggunakan POM-QM}

Bentuk analisis yang digunakan yaitu metode VAM dengan bantuan program POM-QM. POMQM for Windows adalah sebuah progam komputer yang digunakan untuk memecahkan masalah dalam bidang produksi dan manajemen operasi yang bersifat kuantitatif. Untuk penyelesaian model tranportasi dengan POM QM digunakan data pada tabel 9. Langkah-langkah penyelesaiannya adalah

a) Menjalankan POM-QM

Klik dua kali simbol jalan pintas POM-QM di layar utama pada komputer.

b) Pilih satuan pengukur yang akan digunakan

Satuan pengukur yang akan digunakan untuk menyelesaikan masalah ini adalah transportation. Satuan pengukur ini digunakan untuk mengatur distribusi dari sumbersumber yang menyediakan produk yang sama ke tempat-tempat yang membutuhkan secara optimal biaya yang termurah.

Langkah penyelesaiannya berikutnya yaitu

- $\quad$ Klik file, pilih new

- Kemudian lengkapi data sesuai data yang digunakan

Title :Judul permasalahan

Number of sources : Banyaknya sumber yang memproduksi barang, yaitu 2 SPPBE.

Number of destinations :Banyaknya tempat tujuan yang ada pada masalah, yaitu 8 agen.

Objective

:Menggambarkan tujuan pengalokasian sumber daya, pada kasus ini tujuannya adalah minimasi.

- Apabila sudah terisi semua dengan benar, klik OK.

- Masukkan data biaya pendistribusian atau biaya transportasi pada sel-sel yang tersedia. Kemudian pada starting method, pilih salah satu metode yang akan digunakan untuk menyelesaikan masalah transportasi tersebut, terdapat tiga pilihan metode yaitu northwest corner method, minimum cost method, dan vogel's approximation method. Dalam kasus ini akan digunakan vogel's approximation method, kemudian klik solve untuk melihat hasilnya

Output hasil penyelesaiannya terdapat 6 output (tampilan) yang dihasilkan dari penyelesaian soal, dimana keenam output tersebut telah dilampirkan pada bagian lampiran.

I. Output transportation shipments merupakan tabel yang menjelaskan jumlah unit yang harus dialokasikan dari sumber ke tujuan, berdasarkan output transportation shipments dapat diketahui sebagai berikut 
- SPPBE TYD yang beralokasi di matungkas harus mengirim LPG $3 \mathrm{~kg}$ ke agen di manado sebanyak 5.765.720 tabung dan ke agen di tomohon sebanyak 1.213.520 tabung.

- SPPBE SPC yang beralokasi di liwas harus mengirim LPG $3 \mathrm{~kg}$ ke agen di manado sebanyak 1.510.880 tabung, ke agen di minahasa sebanyak 2.570.920 tabung, ke agen di minsel sebanyak 1.240.400 tabung, ke agen di minut sebanyak 1.083.040 tabung, ke agen di bolmong sebanyak 416.640 tabung, ke agen di mitra sebanyak 852.320 tabung dan ke agen di kotamobagu sebanyak 1.464 .400 tabung.

Dengan pengalokasian tersebut maka akan diperoleh biaya transportasi yang optimal yaitu sebesar Rp. 2.679.767.000

II. Output marginal cost merupakan tabel yang menjelaskan tambahan biaya yang terjadi apabila kita mengalokasikan tidak sesuai dengan tabel solution. Berdasarkan hasil output tersebut, perusahaan akan mengeluarkan tambahan biaya sebesar dengan yang terdapat pada tabel marginal cost.

Berdasarkan hasil outpunya yang diperoleh,

- SPPBE TYD akan mengeluarkan biaya tambahan sebesar Rp.99 apabila perusahaan akan memaksakan mengalokasikan dari SPPBE TYD Matungkas ke agen yang berada di wilayah Minahasa, biaya tambahan sebesar Rp.103 apabila perusahaan akan memaksakan mengalokasikan dari SPPBE TYD Matungkas ke agen yang berada di wilayah Minsel, biaya tambahan sebesar Rp.182 apabila perusahaan akan memaksakan mengalokasikan dari SPPBE TYD Matungkas ke agen yang berada di wilayah Minut, biaya tambahan sebesar Rp.311 apabila perusahaan akan memaksakan mengalokasikan dari SPPBE TYD Matungkas ke agen yang berada di wilayah Bolmong, biaya tambahan sebesar Rp.47 apabila perusahaan akan memaksakan mengalokasikan dari SPPBE TYD Matungkas ke agen yang berada di wilayah Mitra, dan biaya tambahan sebesar Rp.27 apabila perusahaan akan memaksakan mengalokasikan dari SPPBE TYD Matungkas ke agen yang berada di wilayah Kotamobagu dikarenakan pada solution table SPPBE TYD Matungkas tidak dalokasikan ke agen-agen yang berada di wilayah-wilayah tersebut.

- SBBE SPC Liwas akan mengeluarkan biaya tambahan sebesar Rp.12 apabila perusahaan akan memaksakan mengalokasikan dari SPPBE SPC Liwas ke agen yang berada di wilayah Tomohon

III. Output Final solution table menunjukkan besarnya alokasi dari daerah asal (sumber) ke daerah tujuan (destination) dan nilai marginal cost-nya.

- Besarnya alokasi SPPBE TYD Matungkas ke agen yang berada di wilayah Manado adalah 5.765.720 tabung dan ke agen yang berada di wilayah Tomohon adalah 1.213.520 tabung, sedangkan nilai marginal cost atau biaya tambahan yang harus dikeluarkan SPPBE TYD Matungkas jika memaksakan pengalokasian ke agen yang berada di wilayah Minahasa yaitu sebesar Rp. 99, ke agen yang berada di wilayah Minsel yaitu sebesar Rp. 103, ke agen yang berada di wilayah Minut yaitu sebesar Rp. 182, ke agen yang berada di wilayah Bolmong yaitu sebesar Rp. 311, ke agen yang berada di wilayah Mitra yaitu sebesar Rp. 47, dan ke agen yang berada di wilayah Kotamobagu yaitu sebesar Rp. 27.

- Besarnya alokasi SPPBE SPC Liwas ke agen yang berada di wilayah Manado adalah 1.510.880 tabung, ke agen yang berada di wilayah Minahasa adalah 2.570.920 tabung, ke agen yang berada di wilayah Minsel adalah 1.240.400 tabung, ke agen yang berada di wilayah Minut adalah 1.083.040 tabung, ke agen yang berada di wilayah Bolmong adalah 416.640 tabung, ke agen yang berada di wilayah Mitra adalah 852.320 tabung dan ke agen yang berada di wilayah Kotamobagu adalah 1.464 .400 tabung, sedangkan nilai marginal cost atau biaya tambahan yang harus dikeluarkan SPPBE SPC Liwas jika memaksakan pengalokasian ke agen yang berada di wilayah Tomohon yaitu sebesar Rp. 12.

IV. Tabel iterations merupakan tabel yang menjelaskan tahapan perhitungan seperti tahapan perhitungan manual yang dilalui hingga diperoleh solusi optimal. Berdasarkan hasil output iterations tersebut, pada permasalahan ini terdapat 2 kali iterasi untuk mencapai solusi optimal. 
V. Shipments with costs merupakan tabel yang menunjukkan besarnya alokasi dan biaya yang diperlukan untuk pengalokasian tersebut. Berdasarkan hasil output tersebut, nilai shipments with costs merupakan biaya pengalokasian dari setiap SPPBE ke setiap agen.

Berdasarkan output yang dihasilkan

- Biaya pengalokasian dari SPPBE TYD Matungkas ke agen wilayah Manado adalah Rp.340.177.500 nilai ini didapatkan dari kapasitas pengiriman dikalikan dengan biaya pengiriman (5.765.720 tabung x Rp.59) dan biaya pengalokasian ke agen wilayah Tomohon adalah Rp.203.871.400.

- Biaya pengalokasian dari SPPBE SPC Liwas ke agen wilayah Manado adalah Rp.75.544.000 nilai ini didapatkan dari kapasitas pengiriman dikalikan dengan biaya pengiriman (1.510880 tabung x Rp. `50), selanjutnya biaya pengalokasian ke agen wilayah Minahasa adalah Rp.352.216.000, biaya pengalokasian ke agen wilayah Minsel adalah Rp.334.908.000, biaya pengalokasian ke agen wilayah Minut adalah Rp.106.137.900, biaya pengalokasian ke agen wilayah Bolmong adalah Rp.272.065.900, biaya pengalokasian ke agen wilayah Mitra adalah Rp.258.253.000, dan biaya pengalokasian ke agen wilayah Kotamobagu adalah Rp.736.593.200.

VI. Shipping list merupakan tabel yang menunjukkan rincian pengalokasian biaya per unit dan biaya total tiap pengalokasian. Tabel ini merupakan ringkasan dari keseluruhan output sebelumnya.

Berdasarkan hasil output yang dihasilkan, dapat diketahui bahwa

- Dari SPPBE TYD Matungkas ke agen wilayah Manado sebanyak 5.765.720 tabung (shipment) dengan biaya per unit sebesar Rp.59 (cost per unit) sehingga biaya total untuk pengiriman tersebut sebesar Rp.340.177.500 (shipment cost) dan ke agen wilayah Tomohon sebanyak 1.213.520 tabung (shipment) dengan biaya per unit sebesar Rp.168 (cost per unit) sehingga biaya total untuk pengiriman tersebut sebesar Rp.203.871.400 (shipment cost).

- Dari SPPBE SPC Liwas ke agen wilayah Manado sebanyak 1.510.880 tabung (shipment) dengan biaya per unit sebesar Rp.50 (cost per unit) sehingga biaya total untuk pengiriman tersebut sebesar Rp.75.544.000 (shipment cost), ke agen wilayah Minahasa sebanyak 2.570.920 tabung (shipment) dengan biaya per unit sebesar Rp.137 (cost per unit) sehingga biaya total untuk pengiriman tersebut sebesar Rp.352.216.000 (shipment cost), ke agen wilayah Minsel sebanyak 1.240 .400 tabung (shipment) dengan biaya per unit sebesar Rp.270 (cost per unit) sehingga biaya total untuk pengiriman tersebut sebesar Rp.334.908.000 (shipment cost), ke agen wilayah Minut sebanyak 1.083.040 tabung (shipment) dengan biaya per unit sebesar Rp.98 (cost per unit) sehingga biaya total untuk pengiriman tersebut sebesar Rp.106.137.900 (shipment cost), ke agen wilayah Bolmong sebanyak 416.640 tabung (shipment) dengan biaya per unit sebesar Rp.653 (cost per unit) sehingga biaya total untuk pengiriman tersebut sebesar Rp.272.065.900 (shipment cost), ke agen wilayah Mitra sebanyak 852.320 tabung (shipment) dengan biaya per unit sebesar Rp.303 (cost per unit) sehingga biaya total untuk pengiriman tersebut sebesar Rp.258.253.000 (shipment cost), dan ke agen wilayah Kotamobagu sebanyak 1.464.400 tabung (shipment) dengan biaya per unit sebesar Rp.503 (cost per unit) sehingga biaya total untuk pengiriman tersebut sebesar Rp.736.593.200 (shipment cost).

\section{Kesimpulan}

a. Dengan mengimplementasikan model transportasi distribusi menggunakan Metode Pendekatan Vogel (Vogel's Approximation Method) dapat menghemat biaya transportasi distribusi pada LPG $3 \mathrm{~kg}$ di Sulawesi Utara. Penghematan biaya pendistribusian masih dapat berkurang, karena perhitungan biaya pendistribusian tersebut mengabaikan asumsi-asumsi, seperti uang intensif sopir, pemakaian bahan bakar, dan lainnya.

b. SPPBE Tambang Yoko Delta di Matungkas dan SBBPE Sinar Pratama Cemerlang di Liwas memiliki metode sendiri dalam melakukan pendistribusian produknya berupa LPG $3 \mathrm{~kg}$ ke beberapa daerah tujuannya. Dengan menggunakan metode Pendekatan Vogel (Vogel's Approximation Method), perusahaan mengeluarkan biaya transportasi dalam mendistribusikan 
LPG 3kg setahunnya sebesar Rp. 2.679.767.000 dengan jumlah produk sebanyak 16.117 .840 tabung LPG $3 \mathrm{~kg}$.

\section{Daftar Pustaka}

[1] Yuwono, B dan P. Istiani. Bahan Kuliah Riset Operasi. UPN Veteran Yogyakarta. Yogyakarta

[2] Anonim. 2014. Jalur Distribusi Elpiji. http://www.pertamina.com/gasdom/ fasilitas dan distribusi jalurdistribusi.aspx?type=elpiji [ 21 Oktober 2014]

[3] Pontoh, M. 2011. Penyelesaian Masalah Transportasi Produk Aqua dengan Menggunakan North West Corner dan Stepping Stone (Skripsi). Manado : Universitas Sam Ratulangi

[4] Simbolan, L. D. dan M. Situmorang. 2014. Aplikasi Metode Transportasi Dalam Optimasi Biaya Distribusi Beras Miskin (Raskin) Pada Perum Bulog Sub Divre Medan. Saintia Matematika. 2(3) : 299-311.

[5] Nirwansah, H. dan Widowati. 2007. Efisiensi Biaya Distribusi dengan Metode Transportasi.FMIPA UNDIP, Semarang.

[6] Nelwan, C., J. Kekenusa dan Y. Langi. Optimasi Pendistribusian Air Dengan Menggunakan Metode Least Cost Dan Metode Modified Distribution (Studi Kasus: PDAM Kabupaten Minahasa Utara). Jurnal Ilmiah Sains. 13(1)

[7] Woodward, F.H. 1982. Manajemen Transportasi PT. Pustaka Binaman Pressindo. Jakarta.

[8] Zainuddin 2011. Analisis Penerapan Model Transportasi dan Distribusi (Dengan VAM dan MODI) Pada PT. Coca-Cola Bottling Indonesia (Skripsi). Makassar : Universitas Hassanudin Makassar. 